\title{
Analisis Finansial Usaha Budidaya Rumput Laut dan Nilai Tambah Tepung Karaginan di Kecamatan Kei Kecil, Kabupaten Maluku Tenggara
}

\author{
Anna Kartika Ngamel \\ Program Studi Agribisnis Perikanan, Politeknik Perikanan Negeri Tual \\ annangamel@yahoo.com
}

Diterima 22 Juni 2012/Disetujui 25 Oktober 2012

\begin{abstract}
The purpose of this study was to calculate the financial analysis of seaweed cultivation operation and count the number of value-added processing karaginan flour mill in the District of Southeast Maluku Regency Kei Kecil. The method used in this study is descriptive with qualitative and quantitative approaches. Determination of the location of the study was conducted purposively with its population was seaweed farmers from ten villages in Kei Kecil as the villages of seaweed production centers. The method of analysis used is the operation analysis of financial and added value analysis method Hayami. The results showed that the cultivation of seaweed and flour mills karaginan feasible to develop. The ratio of added value of $9.05 \%$ and in 1997 Hubeis magnitude of the ratio of value added is calculated in accordance with the criteria of low added value ratio $<15 \%$.
\end{abstract}

Keywords: Financial Analysis, Added-value, Seaweed, Flour Caragenan.

\section{PENDAHULUAN}

Agribisnis rumput laut termasuk di dalamnya industri pengolahan rumput laut menjadi tepung karaginan sebagaimana bisnis berbasis hasil pertanian lainnya memerlukan keterkaitan yang erat antara hulu (up stream) dan hilir (down stream). Hal ini dikarenakan pada tingkat hulu (petani atau nelayan) memiliki keahlian dan kemauan dalam berproduksi dan keterbatasan dalam mengakses pasar dan teknologi. Sementara itu di tingkat hilir, dalam hal ini pemilik pabrik, memiliki kekuatan dalam hal teknologi dan akses pasar, namun membutuhkan kontinuitas dalam ketersediaan bahan baku (Sulaeman S, 2006).

Wilayah Kabupaten Maluku Tenggara merupakan salah satu wilayah sentra pengembangan budidaya rumput laut telah ditetapkan oleh pemerintah sebagai salah satu kabupaten yang masuk dalam klaster pilihan di Provinsi Maluku untuk pengembangan industri pengolahan rumput laut hingga tahun 2013 mendatang. Hal ini didukung dengan potensi lahan yang tersedia untuk pengembangan budidaya rumput laut yang sangat luas, yaitu sekitar 5.103 ha dari total luas lahan potensial budidaya hasil laut sebesar 10.900,76 ha. Wilayah Kecamatan Kei Kecil sebagai kecamatan induk dan juga sentra produksi rumput laut dipilih sebagai wilayah penelitian. Jenis rumput laut yang umumnya dibudidayakan dan diproduksi di Kabupaten Maluku Tenggara adalah Eucheuma cottonii dan Eucheuma spinosum. Kegiatan budidaya rumput laut jenis Eucheuma sp ini mudah dilaksanakan, karena masih menggunakan teknologi sederhana atau alat tradisional dalam proses penanaman hingga panen. Sebagian besar masyarakat pesisir Kabupaten Maluku Tenggara bekerja sebagai petani rumput laut, sehingga mengakibatkan produksi rumput laut menjadi semakin meningkat yang dapat dilihat pada Tabel 1. 
Tabel 1. Perkembangan Volume Produksi dan Nilai Produksi Rumput Laut di Kabupaten Maluku Tenggara, Tahun $2007-2009$.

\begin{tabular}{cccc}
\hline No & Tahun & Volume (Ton) & Produksi \\
& 2007 & 44,10 & Nilai (Rp) \\
\hline 1 & 2008 & 381,12 & $220.500 .000,-$ \\
2 & 2009 & $3.285,00$ & $5.716 .800 .000,-$ \\
3 & 2010 & $39.420 .000 .000,-$ \\
\hline
\end{tabular}

Pada Tabel 1 terlihat bahwa produksi rumput laut mulai tahun 2007 hingga 2009 mengalami kenaikan yang cukup signifikan, namun keadaan tersebut belum mampu menciptakan pasar secara baik dan tepat serta belum mampu memberikan nilai tambah terhadap pengolahannya. Untuk itu, analisis keuangan dan nilai tambah perlu dilakukan terhadap usaha petani budidaya rumput laut ketika komoditas rumput laut tersebut telah berubah bentuk menjadi tepung karaginan melalui proses pengolahannya. Kegiatan petani yang selama ini dilakukan adalah budidaya rumput laut sebagai bentuk usaha tani yang hasil panennya dikeringkan, kemudian dijual. Permasalahan yang terjadi bahwa keberadaan koperasi tani dan nelayan selama ini sebagai lembaga masyarakat belum mampu mengakses pasar. Pada waktu musim panen rumput laut basah dan kering terjual melalui pedagang pengumpul dengan harga yang tidak stabil. Harga ini ditentukan oleh pengumpul, karena petani belum mempunyai bargaining power dalam penentuan harga jual, namun masyarakat petani tetap berupaya menanam rumput laut dengan harapan bahwa suatu saat rumput laut dapat terjual dengan harga yang diinginkan oleh petani. Melalui koperasi, saat ini pabrik tepung karaginan baru dibangun, namun belum berjalan secara normal. Hal ini tentunya juga perlu mendapat dukungan dari pemerintah daerah terhadap pengembangan pabrik pengolahan tepung karaginan yang masih dalam tahap percobaan, sehingga nantinya dapat menjadi produk unggulan. Dengan demikian, terjalin kerja sama antara masyarakat yang dalam hal ini petani rumput laut yang bermitra dengan koperasi, kelembagaan masyarakat yaitu koperasi dan pemerintah. Berdasarkan latar belakang dan permasalahan diatas, maka tujuan dari kegiatan penelitian ini adalah menghitung secara finansial usaha budidaya rumput laut dan menghitung besarnya nilai tambah pengolahan rumput laut menjadi tepung karaginan di wilayah penelitian.

\section{METODOLOGI}

Dalam usaha tani, seseorang mengalokasikan sumber daya secara efektif dan efisien untuk tujuan memperoleh keuntungan yang tinggi pada waktu tertentu. Dikatakan efektif apabila petani atau produsen dapat mengalokasikan sumberdaya yang dimiliki, dan dikatakan efisien bila pemanfaatan sumber daya tersebut menghasilkan keluaran atau output yang melebihi masukan/sarana (Soekartawi, 1995). Salah satu kegiatan yang harus dilakukan agar suatu produk mempunyai nilai tambah adalah dengan pengolahan hasil pertanian yang mencakup perikanan dan kelautan, peternakan, kehutanan dan perkebunan. Kegiatan pengolahan hasil pertanian menjadi penting karena pertimbangan diantaranya, yaitu meningkatkan nilai tambah, meningkatkan kualitas hasil, meningkatkan penyerapan tenaga kerja, meningkatkan keterampilan dan meningkatkan pendapatan produsen. Dari sini jelas bahwa pengolahan yang baik akan menghasilkan nilai tambah yang besar pula. Nilai tambah bagi kegiatan agroindustri dapat terjadi sebagai akibat proses produksi yang mentransformasikan input agroindustri menjadi output agroindustri (Martin et.al., 1991).

Maluku Tenggara memiliki potensi sumber daya kelautan dan perikanan yang melimpah. Hal ini didukung dengan adanya luas wilayah lautan yang lebih besar dibandingkan luas wilayah daratan. Salah satu potensinya yang menjadi primadona 
adalah rumput laut dengan peluang pasar yang masih terbuka, ketika bahan mentah rumput laut diolah menjadi tepung karaginan (food grade). Kondisi umum yang terjadi di wilayah penelitian seperti transportasi jalan yang kurang memadai, peran koperasi sebagai lembaga masyarakat yang belum mampu menciptakan pasar padahal potensi kelautan mendominasi. Hal ini semakin membuat bargaining power petani rumput laut lemah, karena harga jual rumput laut yang belum sesuai dengan keinginan petani. Melihat peluang dan gambaran umum dari kondisi di wilayah ini, maka tentunya harus disertai dukungan dari berbagai pihak khususnya pemerintah seperti perbaikan sarana transportasi jalan, pembinaan atau penyuluhan kepada para petani rumput laut dan penguatan kelembagaan. Dukungan yang diberikan oleh pemerintah salah satunya dengan penguatan kelembagaan seperti koperasi tani dan nelayan sangat membantu para petani rumput laut meningkatkan produksinya dan mengakses pasar. Hal ini tentunya melalui pola kemitraan yang dijalankan antara pihak pengelola pabrik dalam hal ini adalah koperasi dengan para petani rumput laut, sehingga harga jual dapat disesuaikan dengan keinginan para petani demi kesejahteraan hidupnya. Penguatan lembaga seperti koperasi tani dan nelayan yang berkembang saat ini di wilayah penelitian baru memulai menerapkan pola kemitraan dengan para petani rumput laut, karena pabrik pengolahan rumput laut telah ada yang pengolahannya masih dilakukan dalam tahap percobaan. Untuk itu, perlu dilakukan analisis terhadap perkembangan pabrik pengolahan tepung karaginan melalui analisis finansial dan analisis nilai tambah yang bertujuan melihat layak atau tidaknya usaha tani dan nilai tambah dari proses perubahan bentuk bahan mentah berupa rumput laut basah menjadi produk setengah jadi yaitu tepung karaginan agar dapat memberikan manfaat bagi masyarakat.

Alat analisis sederhana yang dapat digunakan untuk mengkaji kelayakan finansial adalah $R / C$ Ratio, $B E P$ harga, $B E P$ produk. Apabila hasil perhitungan menunjukkan bahwa nilai $R C$ Ratio dan $B E P$ sesuai dengan kriteria kelayakan, maka usaha budidaya rumput laut layak untuk terus dikembangkan, sehingga dapat dilanjutkan untuk mengembangkan usaha industri pengolahan tepung karaginan. Alur berpikir penelitian ini dapat dilihat dalam Gambar 1.

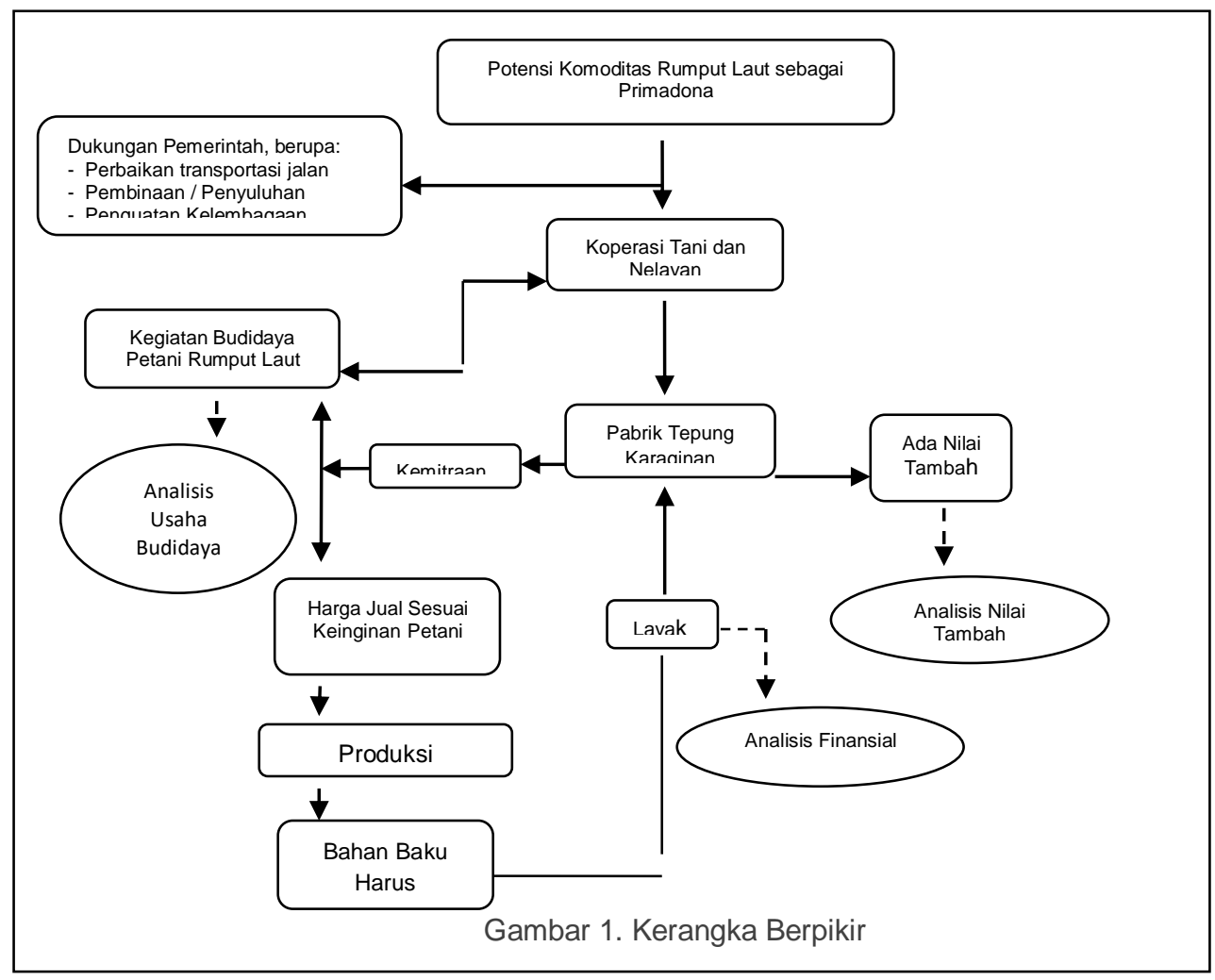




\section{Metodologi Penelitian}

Penelitian ini menggunakan metode penelitian deskriptif yang dilakukan secara survey dengan populasi yang berasal dari petani rumput laut. Pendekatan yang dilakukan adalah secara kualitatif dan kuantitatif. Lokasi penelitian dilakukan secara sengaja (purposive) yang terletak pada sepuluh desa sentra produksi rumput laut di wilayah Kecamatan Kei Kecil, Kabupaten Maluku Tenggara. Penelitian ini dilaksanakan pada Bulan Juni - April 2011. Alasan pemilihan lokasi ini, karena merupakan wilayah sentra produksi rumput laut terbesar dari lima kecamatan lainnya dan sebagai induk kecamatan di Kabupaten Maluku Tenggara.

Berdasarkan sumbernya, data yang dikumpulkan dalam penelitian ini meliputi data primer dan data sekunder. Setelah survey pendahuluan dilakukan, maka diperoleh keterangan bahwa sepuluh desa sebagai populasi di Kecamatan Kei Kecil merupakan desa yang jumlah petani rumput lautnya terbanyak dibanding desa-desa lainnya. Dari kesepuluh desa tersebut diambil 100 responden yang ditentukan secara proporsional sampling. Pengambilan 100 responden adalah $10 \%$ dari jumlah populasi mengingat populasi di wilayah penelitian adalah homogen. Hal ini mengacu pada literatur Gay, 1976 dalam Sevilla C.G, dkk, 1993 yang menawarkan beberapa ukuran minimum pengambilan responden yang dapat diterima berdasarkan tipe penelitian, yaitu bahwa penelitian deskriptif dengan jumlah populasi yang banyak minimal 10\% diambil dari jumlah populasi. Untuk lebih jelasnya metode pengambilan responden dapat dijelaskan pada Tabel 2. berikut.

\section{Metode Analisis Data}

Analisis data merupakan proses penyederhanaan data ke dalam bentuk yang lebih mudah dibaca dan diinterpretasikan. Data yang diperoleh ditampilkan dalam bentuk tabel dan dianalisis secara deskriptif. Data-data yang telah dikumpulkan dihitung atau dianalisis dengan menggunakan alat analisis usaha tani budidaya rumput laut, kelayakan investasi dan nilai tambah metode Hayami.

Tabel 2. Pengambilan 100 Responden di Wilayah Penelitian

\begin{tabular}{|c|c|c|c|}
\hline No & Nama Desa & $\begin{array}{c}\text { Jumlah Populasi } \\
\text { (Petani Rumput Laut) }\end{array}$ & $\begin{array}{c}\text { Jumlah Responden Secara } \\
\text { Proporsional }\end{array}$ \\
\hline 1 & Sathean & 273 orang & 26 \\
\hline 2 & Letvuan & 207 orang & 19 \\
\hline 3 & Ohoidertavun & 111 orang & 10 \\
\hline 4 & Wab & 109 orang & 10 \\
\hline 5 & Letman & 85 orang & 8 \\
\hline 6 & Evu & 63 orang & 6 \\
\hline 7 & Kelanit & 62 orang & 6 \\
\hline 8 & Ibra & 57 orang & 5 \\
\hline 9 & Namar & 55 orang & 5 \\
\hline 10 & Ohoililir & 49 orang & 5 \\
\hline & Total & 1071 orang & 100 \\
\hline
\end{tabular}

Sumber: data primer, 2011

\section{1) Analisis Finansial Usaha Tani}

Menurut Sugiarto, dkk. (2005) analisis unit usaha yang sederhana dapat dilakukan dengan menggunakan formula Total Cost (TC), Total Revenue (TR) dan Keuntungan $(\pi)$. Total cost adalah keseluruhan biaya yang dikeluarkan dalam menghasilkan output. Total revenue adalah jumlah penerimaan total suatu perusahaan yang diperoleh dari besarnya tingkat produksi dikalikan dengan tingkat harga. 
Keuntungan dapat diperoleh dari total penerimaan dikurangi dengan total biaya yang dikeluarkan. Effendi dan Oktariza (2006) menjelaskan bahwa analisis Revenue Cost Ratio ( $R / C$ Rasio) merupakan alat analisis untuk melihat keuntungan relatif suatu usaha dalam satu tahun terhadap biaya yang dipakai dalam kegiatan tersebut. Kriteria yang digunakan dalam analisis $\mathrm{R} / \mathrm{C}$ rasio sebagai berikut:

- Jika nilai $\mathrm{R} / \mathrm{C}$ rasio $>1$ usaha dikatakan layak dan menguntungkan,

- Jika nilai $R / C$ rasio $<1$ usaha dikatakan tidak layak dan tidak menguntungkan,

- Jika nilai $\mathrm{R} / \mathrm{C}$ rasio $=1$ usaha dikatakan impas (tidak untung dan tidak rugi).

Analisis BEP (Break Event Point) merupakan alat analisis untuk mengetahui batas nilai produksi atau volume produksi suatu usaha mencapai titik impas (tidak untung dan tidak rugi). Total cost (TC) adalah nilai keseluruhan biaya yang dikeluarkan merupakan penjumlahan antara biaya tetap dan biaya variabel.

\section{2) Analisis Nilai Tambah (Added Value)}

Ada dua cara untuk menghitung nilai tambah yaitu nilai tambah untuk pengolahan dan nilai tambah untuk pemasaran. Besarnya nilai tambah yang dapat diketahui dengan Metode Hayami ini juga digunakan untuk mengetahui informasi mengenai besarnya pendapatan bagi tenaga kerja langsung serta keuntungan tanpa memperhatikan biaya tetap. Penelitian ini menggunakan metode penghitungan nilai tambah untuk pengolahan dengan formula yang dapat dilihat pada Tabel 3. (Hayami, 1987 dalam Sudiyono, 2001).

\section{HASIL DAN PEMBAHASAN}

\section{Analisis Kelayakan Finansial Usaha Tani}

Analisis kelayakan finansial usaha tani digunakan untuk mengetahui tingkat kelayakan secara finansial dari petani dalam melakukan usahanya. Dalam penelitian ini, usaha tani yang dilihat adalah kegiatan budidaya rumput laut jenis Eucheuma cottonii dan Eucheuma spinosum. Rata-rata dalam setahun responden di wilayah penelitian melakukan kegiatan musim tanam sebanyak 5 (lima) kali, sehingga dalam analisis ini perhitungan biaya total, penyusutan, besarnya penerimaan dan keuntungan yang dilakukan adalah per produksi. Besarnya peralatan sebagai biaya investasi rata-rata usaha budidaya rumput laut di wilayah penelitian yang digunakan untuk modal usaha dapat dilihat pada Tabel 4.

Tabel 4. Harga Rata-Rata Peralatan dan Penyusutan Usaha Budidaya Rumput Laut di Kecamatan Kei Kecil Kabupaten Maluku Tenggara, Tahun 2010

\begin{tabular}{rlrcr}
\hline No & Jenis Barang & Nilai (Rp) & $\begin{array}{c}\text { Umur } \\
\text { Ekonomis }\end{array}$ & $\begin{array}{c}\text { Penyusutan per } \\
\text { Produksi }\end{array}$ \\
\hline 1 & Tali & 138.900 & 2 tahun & 13.890 \\
2 & Pelampung & 36.650 & 1 tahun & 7.330 \\
3 & Jangkar & 96.400 & 2 tahun & 9.640 \\
4 & Sampan & 1.106 .100 & 4 tahun & 55.305 \\
5 & Penjemuran & 219.600 & 1 tahun & 43.920 \\
6 & Plastik bening & 106.330 & 1 tahun & 21.266 \\
7 & Pisau /gunting & 19.460 & 1 tahun & 3.892 \\
8 & Jaring bagan & 93,200 & 5 tahun & 3.728 \\
9 & Terpal & 155,050 & 1 tahun & 31.010 \\
\hline \multicolumn{2}{c}{ Total Investasi } & $\mathbf{1 . 9 7 1 . 6 9 0}$ & & 189.981 \\
\hline
\end{tabular}

Sumber: data primer diolah 
Berdasarkan Tabel 4, terlihat bahwa modal rata-rata yang dimiliki oleh responden sebesar Rp 1.971.690,- yang dibulatkan menjadi Rp 1.972.000,-. Besarnya rata-rata biaya penyusutan adalah Rp189.981,- dengan angka pembulatan sebesar Rp 190.000,-. Peralatan dan penyusutan ini digunakan dalam perhitungan untuk satu kali produksi. Besarnya biaya total yang meliputi biaya tetap dan biaya variabel yang dikeluarkan untuk kegiatan budidaya rumput laut dapat dilihat pada Tabel 5 .

Tabel 5. Rata-Rata Biaya Operasional Produksi Usaha Budidaya Rumput Laut di Kecamatan Kei Kecil Kabupaten

Maluku Tenggara,Tahun 2011

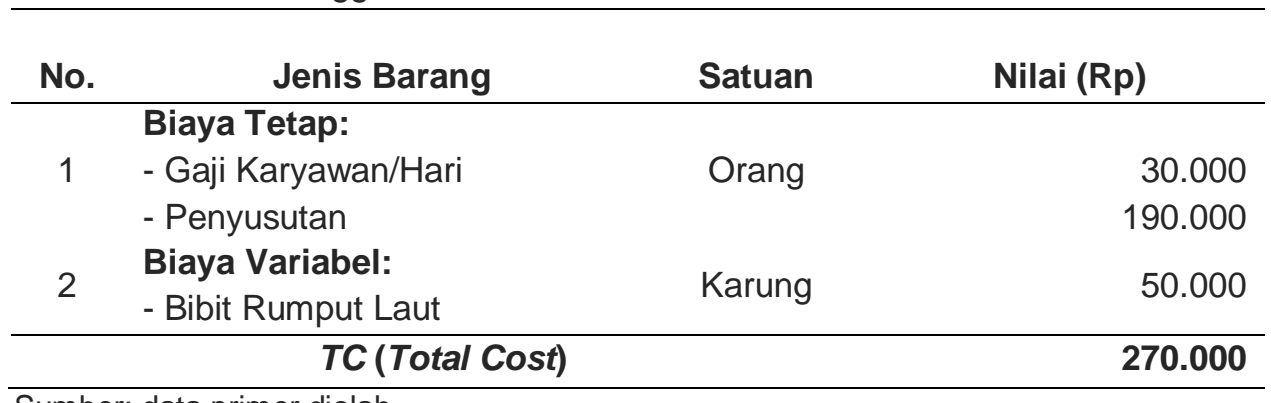

Sumber: data primer diolah

Berdasarkan Tabel 5. terlihat bahwa besarnya biaya tetap per produksi adalah Rp 220.000,- dan biaya variabel sebesar $R p 50.000,-$. Total biaya yang dikeluarkan untuk melakukan budidaya rumput laut sebesar Rp $270.000,-$. Total biaya ini digunakan dalam satu kali proses produksi budidaya rumput laut. Besarnya rata-rata penerimaan petani rumput laut di wilayah penelitian dengan menggunakan formula $T R=P \times Q$, besarnya penerimaan rata-rata untuk 100 responden di wilayah penelitian sebesar Rp 506.400,yang dihitung berdasarkan jumlah produksi rata-rata responden sebanyak $422 \mathrm{~kg}$ dengan harga rata-rata sebesar Rp 1.200,- untuk satu kali produksi. Dengan demikian besarnya penerimaan total atau TR (total revenue) yang diperoleh merupakan penerimaan per produksi. Besarnya nilai $T R$ dan $T C$ telah diketahui, sehingga rata-rata keuntungan yang diperoleh 100 responden sebesar pengurangan dari nilai $T R$ dan TC, yaitu: $\Pi$ (keuntungan) $=T R-T C$, sehingga $\Pi=R p$ 506.400,- - Rp 270.000,- menjadi Rp236.400,- yang merupakan keuntungan dari rata-rata responden di wilayah penelitian. Perhitungan yang dilakukan adalah sebagai berikut :

$R / C=$ Penerimaan / Biaya Tetap + Biaya Variabel

$$
=506.400 / 220.000+50.000
$$

$R / C=1,88$ dengan angka pembulatan sebesar 1,9 .

Jadi, besarnya nilai $R / C>1$ maka usaha yang dijalankan adalah layak. Nilai $\mathrm{R} / \mathrm{C}$ sebesar 1,88 mempunyai arti bahwa setiap biaya produksi yang dikeluarkan sebesar Rp1000,-, maka akan diperoleh penerimaan sebesar Rp1880,-. Besarnya nilai Break Event Point $(B E P)$ dapat dihitung dengan menggunakan formula sebagai berikut:

$B E P$ Produksi $=$ Total Biaya $/$ Harga Penjualan

$$
\begin{aligned}
& =\mathrm{Rp} 270.000 / \mathrm{Rp} 1.200 \\
& =225 \mathrm{~kg}
\end{aligned}
$$

$B E P$ Harga $=$ Total Biaya $/$ Total Produksi

$=\operatorname{Rp} 270.000 / 422 \mathrm{~kg}$

$=\operatorname{Rp} 640$,-

Jadi, nilai $B E P$ produksi dari hasil perhitungan sebesar $225 \mathrm{~kg}$ mempunyai arti bahwa usaha budidaya rumput laut yang dilakukan di wilayah penelitian mengalami titik impas pada saat produksi usaha mencapai $225 \mathrm{~kg}$. Nilai BEP harga sebesar Rp640,- 
menunjukkan bahwa usaha budidaya rumput laut di wilayah penelitian mengalami titik impas atau tidak untung dan tidak rugi pada saat harga jual rumput laut basah sebesar Rp 640,- per kg.

Tabel 3. Format Analisis Nilai Tambah Pengolahan

\begin{tabular}{|c|c|c|}
\hline \multicolumn{2}{|r|}{ Output, Input, Harga } & Formula \\
\hline 1 & Hasil produksi (kg / tahun) & A \\
\hline 2 & Bahan baku (kg / tahun) & B \\
\hline 3 & Tenaga kerja $(\mathrm{HOK})$ & $\mathrm{C}$ \\
\hline 4 & Faktor konversi (1 / 2) & $A / B=M$ \\
\hline 5 & Koefisien tenaga kerja (3 / 2) & $C / B=N$ \\
\hline 6 & Harga produk $(\mathrm{Rp} / \mathrm{Kg})$ & D \\
\hline 7 & Upah rerata (Rp / HOK) & $\mathrm{E}$ \\
\hline \multicolumn{2}{|r|}{ Pendapatan } & \\
\hline 8 & Harga bahan baku (Rp / kg) & $\mathrm{F}$ \\
\hline 9 & Sumbangan input lain $(\mathrm{Rp} / \mathrm{kg})$ & G \\
\hline 10 & Nilai produk $(4 \times 6)(\mathrm{Rp} / \mathrm{kg})$ & $M \times D=K$ \\
\hline 11 & a. Nilai tambah (10-8-9) $(\mathrm{Rp} / \mathrm{kg})$ & $K-F-G=L$ \\
\hline \multirow[t]{2}{*}{12} & a. Imbalan tenaga kerja $(5 \times 7)(\mathrm{Rp} / \mathrm{kg})$ & $N \times E=P$ \\
\hline & b. Bagian tenaga kerja (12.a. / 11.a.) (\%) & $(P / L) \%=Q \%$ \\
\hline \multirow[t]{3}{*}{13} & a. Keuntungan $(10-11 . a)$ & $K-L=R$ \\
\hline & b. Tingkat keuntungan (13.a / 10) (\%) & $(\mathrm{R} / \mathrm{K}) \%=0 \%$ \\
\hline & Balas Jasa Untuk Faktor Produksi & \\
\hline \multirow[t]{4}{*}{14} & Margin $(\mathrm{Rp} / \mathrm{kg})$ & $\mathrm{K}-\mathrm{F}=\mathrm{S}$ \\
\hline & - Pendapatan tenaga kerja langsung $12 a$ / (14 x 100) & $P /(S \times 100)=T$ \\
\hline & - Sumbangan input lain 9 / (14 x 100) & $G /(S \times 100)=U$ \\
\hline & - Keuntungan perusahaan 13a / (14 x 100) & $R /(S \times 100)=V$ \\
\hline
\end{tabular}

Sumber: Hayami dalam Sudiyono, 2001

\section{Analisis Nilai Tambah}

Analisis nilai tambah dilakukan untuk memperoleh informasi mengenai perkiraan nilai tambah, imbalan tenaga kerja, imbalan bagi modal dan manajemen dari setiap kilogram rumput laut yang diolah menjadi tepung karaginan. Informasi mengenai imbalan bagi faktor-faktor produksi dalam proses produksi ini sangat penting bagi pelaku-pelaku bisnis.

Proses produksi tepung karaginan memerlukan input berupa rumput laut basah dan tenaga kerja sebanyak 5 (lima) orang yang melakukan kegiatan produksi. Peralatan diperlukan untuk mentransformasikan input menjadi output. Bahan penolong yang digunakan dalam proses produksi pengolahan meliputi air bersih dan alkohol $90 \%$. Kapasitas yang digunakan per hari dalam satu kali proses produksi adalah $300 \mathrm{~kg}$ dengan tingkat rendemen sebesar 0,13 atau $13 \%$, sehingga menghasilkan tepung karaginan sebanyak $39 \mathrm{~kg}$. Struktur biaya produksi dan penerimaan pabrik tepung karaginan di Kecamatan Kei Kecil, Kabupaten Maluku Tenggara, dapat dilihat pada Tabel 7. 
Tabel 7. Struktur Biaya Produksi dan Penerimaan Pabrik Pengolahan Rumput Laut Kapasitas 90 ton/tahun di Kecamatan Kei Kecil Kabupaten Maluku Tenggara, Tahun 2011

\begin{tabular}{|c|c|c|}
\hline \multicolumn{2}{|r|}{ Output, Input, Harga } & Nilai \\
\hline 1 & Hasil produksi (kg / tahun) & $11.700,00$ \\
\hline 2 & Bahan baku (kg / tahun) & $90.000,00$ \\
\hline 3 & Tenaga kerja (HOK) & $1.500,00$ \\
\hline 4 & Faktor konversi (1 / 2) & 0,13 \\
\hline 5 & Koefisien tenaga kerja (3 / 2) & 0,02 \\
\hline 6 & Harga produk $(\mathrm{Rp} / \mathrm{Kg})$ & $150.000,00$ \\
\hline 7 & Upah rerata (Rp / HOK) & $36.000,00$ \\
\hline \multicolumn{3}{|c|}{$\begin{array}{l}\text { Pendapatan } \\
\end{array}$} \\
\hline 8 & Harga bahan baku (Rp / kg) & $1.200,00$ \\
\hline 9 & $\begin{array}{l}\text { Sumbangan input lain atau bahan penolong } \\
(\mathrm{Rp} / \mathrm{kg})\end{array}$ & $8.937,50$ \\
\hline 10 & Nilai produk $(\mathrm{Rp} / \mathrm{kg})$ & $19.500,00$ \\
\hline \multirow{2}{*}{11} & a. Nilai tambah (Rp / kg) & $9.362,50$ \\
\hline & b. Rasio nilai tambah (\%) & 48,01 \\
\hline \multirow{2}{*}{12} & a. Imbalan tenaga kerja $(\mathrm{Rp} / \mathrm{kg})$ & 720,00 \\
\hline & b. Bagian tenaga kerja (\%) & 0,077 \\
\hline \multirow[t]{2}{*}{13} & a. Keuntungan $(\mathrm{Rp} / \mathrm{kg})$ & $10.137,50$ \\
\hline & •Pendapatan tenaga kerja langsung & 0,00039 \\
\hline & Balas Jasa Untuk Faktor Produksi & \\
\hline \multirow[t]{3}{*}{14} & Margin $(\mathrm{Rp} / \mathrm{kg})$ & $18.300,00$ \\
\hline & - Sumbangan input lain & 0,00488 \\
\hline & - Keuntungan perusahaan & 0,00554 \\
\hline
\end{tabular}

Sumber: data diolah

Berdasarkan Tabel 7. terlihat bahwa dengan menggunakan bahan baku yang berupa rumput laut sebanyak $90.000 \mathrm{~kg} /$ tahun dapat menghasilkan tepung karaginan sebanyak $11.700 \mathrm{~kg}$. Usaha ini mampu menyerap tenaga kerja sebanyak 1500 HOK/tahun. Dengan demikian, curahan tenaga kerja yang dibutuhkan untuk mengolah 1 $\mathrm{kg}$ rumput laut menjadi tepung karaginan sebanyak 0,02 HOK/tahun. Apabila harga output sebesar Rp150.000,-/kg dan faktor konversi sebesar 0,13, maka nilai produksi sebesar Rp19.500,-. Nilai produksi ini dialokasikan untuk bahan baku yang berupa rumput laut seharga Rp1.200,- dan bahan penolong berupa air bersih senilai Rp 150.000,- per bulan untuk 25 hari kerja ditambah alkohol 90\% senilai $\quad R p$ 2.531.250,yang digunakan selama sebulan untuk 25 hari kerja, sehingga nilai bahan penolong adalah $\mathrm{Rp} 8.937,50$. Dengan demikian, nilai tambah yang tercipta dari setiap kilogram rumput laut adalah senilai $\operatorname{Rp} 9.362,50$ atau $48,01 \%$ dari nilai produksi. Menurut Hubeis (1997), nilai tambah sebesar 48,01\% merupakan nilai tambah tinggi. Soeharjo (1991) mengatakan bahwa besarnya nilai tambah tergantung dari tekonologi yang digunakan dan dari perlakuan pada produk. Penerapan teknologi yang cenderung padat karya akan memberikan proporsi terhadap tenaga kerja yang besar daripada bagian keuntungan bagi pengusaha, sedangkan yang padat modal proporsi tenaga kerja menjadi kecil. Besar kecil proporsi ini tidak berkaitan dengan imbalan tenaga kerja dalam rupiah. Besarnya nilai tambah karena proses pengolahan didapat dari pengurangan biaya bahan baku dan input lain terhadap nilai produksi yang dihasilkan tidak termasuk tenaga kerja, sehingga nilai tambah merupakan imbalan bagi tenaga kerja dan keuntungan pengolah. 
Imbalan tenaga kerja dari setiap kilogram rumput laut yang diolah menjadi tepung karaginan sebesar Rp 720,-. Dengan demikian pangsa atau bagian tenaga kerja dalam pengolahan rumput laut menjadi tepung karaginan ini sebesar $7,7 \%$. Analisis lebih lanjut menunjukkan bahwa rate keuntungan sebesar 51,99 \% dari nilai produksi, artinya bahwa setiap investasi yang ditanam pada pengolahan tepung karaginan sebesar Rp 100,- dari nilai produksi yang dihasilkan, maka akan diperoleh keuntungan sebesar Rp $51,99,-$. Rate keuntungan ini cukup besar, sehingga harus tetap dipertahankan bahkan harus ditingkatkan dengan cara menekan biaya produksi.

\section{Simpulan}

\section{SIMPULAN DAN SARAN}

Berdasarkan hasil dan pembahasan, maka dapat disimpulkan sebagai berikut :

1. Hasil perhitungan analisis finansial usaha budidaya rumput laut dalam satu kali produksi di wilayah penelitian dengan besarnya nilai $R / C>1$ yaitu 1,9 menunjukkan bahwa usaha tani yang dijalankan berdasarkan kriteria adalah layak dan mempunyai arti bahwa setiap biaya produksi yang dikeluarkan sebesar Rp 1000,-, maka akan diperoleh penerimaan sebesar Rp 1880,-.

2. Pabrik pengolahan rumput laut menjadi tepung karaginan di wilayah Kecamatan Kei Kecil Kabupaten Maluku Tenggara memiliki nilai tambah tinggi yaitu sebesar Rp 9.362,50,- per kg bahan baku atau sebesar 48,01\% dari nilai produksi.

\section{Saran}

Dari hasil penelitian yang telah dilakukan, maka dapat disampaikan beberapa saran sebagai berikut:

1. Diperlukan peran pemerintah dalam penetapan harga jual bahan baku rumput laut mentah agar dapat stabil di wilayah penelitian.

2. Penguatan kelembagaan seperti koperasi harus lebih ditingkatkan agar dapat memberikan kesejahteraan masyarakat khususnya petani rumput laut.

\section{DAFTAR PUSTAKA}

Dinas Kelautan dan Perikanan. 2010. Data Survei Lapangan. Kabupaten Maluku Tenggara

Effendi I dan Oktariza W. 2006. Manajemen Agribisnis Perikanan. Penebar Swadaya. Jakarta.

Hubeis M. (1997). Menuju Industri Kecil Profesional di Era Globalisasi melalui Pemberdayaan Manajemen Industri. Orasi IImiah Guru Besar Tetap IImu Manajemen Industri. Fakultas Teknologi Pertanian. Institut Pertanian Bogor. Bogor.

Martin, L. 1991. Randal Westgreen and Erna van Duren." Agribusiness Competitiveness Across National Buoundaries. American Journal Agricultural Economics. Vol.73.pp. 1474-1475.

Soeharjo, 1991. Konsep dan Ruang Lingkup Agroindustri (Modul II) Penataran Dosen Perguruan Tinggi Swasta Bidang Pertanian Program Kajian Agribsinis. Direktorat Perguruan Tinggi Swasta. Direktorat Jenderal Pertanian. Jakarta.

Soekartawi. 1993. Agribisnis Teori dan Aplikasi. PT. Raja Grafindo Persada. Jakarta.

Soekartawi. 1995. Analisis Usahatani. Universitas Indonesia (UI-Press). Jakarta.

Sudiyono, A. 2001. Pemasaran Pertanian. Universitas Muhammadiyah. Malang

Sugiarto. dkk. 2005. Ekonomi Mikro. Sebuah Kajian Komprehensif. Penerbit PT. Gramedia Pustaka Utama. Jakarta.

Sulaeman S. 2006. Pengembangan Agribisnis Komoditi Rumput Laut melalui Model Klaster Bisnis. Infokop Nomor 28 Tahun XXII. 